traced. Once the FPC is known it is possible to write to them and obtain the name and address of the GP the patient is registered with and to make contact through the patient's GP.

A guide to the use of the National Health Service Central Register (NHSCR) as an aid to medical research is available from the Chief Medical Statistician (Department MR), OPCS, Medical Statistics Division, St. Catherine's House, 10 Kingsway, London WC2B 6JP.

The Central Register proved to be an extremely useful aid in tracing patients in a study ${ }^{1}$ completed recently.

Harsha RATNASURIYa

The Maudsley Hospital

London SES $8 A Z$

REFERENCE

'RAtnasuriya, R. H., Eisler, L., Szmukler, G. I. \& Russell, G. F. M. (1986) Anorexia nervosa: Outcome and prognostic factors after 20 years. (In preparation).

\section{Psychiatry and surrealism}

Dear Sirs

I was interested to read Patrick Bracken's recent account of psychiatry and surrealism (Bulletin, April 1986, $10,80-81)$.

The surrealists freely acknowledged the influence of some psychoanalytical concepts on their work. In fact they considered Eros to be the source of their artistic drive. Breton declared " "Of Eros and the struggle against Eros", in its enigmatic form, this exclamation of Freud's obsesses me some days as only certain passages of poetry can'1. The art historian Robert Short remarked that 'Eros presided over the surrealist experience of beauty in all its forms' 2 .

They were less ready, however, to accept the influence of the death instinct, despite widespread suggestions of its presence in their work. Depersonalised faces haunt Magritte's paintings; morbid desolation pervades Delvaux's 'Call of the Night'; even Bellmer's 'Doll', in spite of its erotic intention, has a cadaverous quality. There are many more examples.

In surrealist art, eroticism and aggression, destruction and creation, life and death are inseparably intertwined. Yet its creators predominantly highlighted the role of Eros and neglected that of the death instinct. But death was not unfamiliar to them; Jacques Vache committed suicide as did Magritte's mother. Perhaps they found unpalatable 'this daemonic concept' described by Freud which 'could bring so little comfort to him or anyone else's.

Greaves Hall Hospital

Patricia Abbott

Southport, Merseyside

References

'Breton, A. (1937) L'Amour Fou. Paris: Gallimard p. 50.

2ShORT, R. (1980) Dada and Surrealism. London: Octopus. p. 147.

${ }^{3}$ Stafrord-Clark, D. (1965) What Freud Really Said. London: Penguin. p. 160.
DeAr Sirs

Patrick Bracken's article on psychiatrists and surrealism opens up some interesting questions but surrealism was never as anti-psychiatric as it claimed. One leading Dadaist, Huelsenbeck, became a psychoanalyst, and Lacan was a surrealist himself, not merely a sympathiser.

The surrealists' response to their erstwhile member Antonin Artaud is significant. Artaud had maintained that 'delirium is as legitimate, as logical, as any other succession of human ideas'1. When he was later hospitalised with schizophrenia he appealed to his former colleagues to rescue him from his doctors: 'The initiates have real instruments of torture ... and they use them from afar to mutilate me a little more every night while I am asleep'2. The surrealists (who had maintained, like the anarchists, that mental patients were political prisoners along with criminals and conscripted soldiers) failed to respond. In practice surrealism accepted the social sequestration of madness. As to the meretricious Dali, Clive Bell correctly pointed out that Freud's aesthetic sensibilities approximated to those of a housemaid; Dali was soon expelled by Breton for his reactionary tendencies.

ROLAND LITTLEWOOD

University of Birmingham

All Saints Hospital

Birmingham

REFERENCES

'Artaud, A. (1970) Lettres aux Medicins- Chefs des Asiles de Fous. Oeuvres Complètes. Paris: Gallimard.

${ }^{2}$ Essurn, M. (1976) Artaud. London: Fontana

\section{Forthcoming Events}

The British Postgraduate Medical Federation are at present holding a series of educational courses and workshops ending in March 1987. Information: Mrs Elva Macklin, Education Department, British Postgraduate Medical Federation, 33 Millman Street, London WCIN 3EJ.

The Midland Course in Group Wort and Family Therapy in association with the Institute of Group Analysis (London) will be holding courses in Oxford (September 1986-May 1987) and in Northampton (October 1986-June 1987) on a weekly half-day basis. They will be of interest to doctors, social workers, psychologists, nurses or others working with small or large groups, including naturally occurring groups. Course fee is $£ 250$. Information: Mrs Ros Clarke, Course Secretary (Oxford), Chaplain's Office, Littlemore Hospital, Littlemore, Oxford OX4 4 XN or to Mrs L. Bardakovic, Course Secretary, Mayfair Day Hospital, 32-34 Headlands, Kettering, Northampton. There is also the possibility, if sufficient interest is shown, for supervision sessions to be arranged for those who have been students on previous Midland Courses. Those interested should write 
to the appropriate Course Secretaries of their interest, giving details of what they are looking for and possible times available.

The Pakistan Psychiatry Society is holding the Sixth Intermational Psychiatric Conference at Lahore from 11-14 December 1986. The main theme is 'Culture and Mental Illness'. Information: Professor I.A.K. Tareen, Head, Department of Psychiatry, Mayo Hospital and King Edward Medical College, Lahore, Pakistan.

The IXth UK/Netherlands Wortelbop in Trerapentic Communities (the Windsor Conference) will be held at Cumberland Lodge, Windsor Great Park, from 15-18 September 1986. The fully inclusive fee is $£ 120.00$. Applications, submissions of papers or other enquiries: Dr J. Stuart Whiteley, Henderson Hospital, 2 Homeland Drive, Brighton Road, Sutton, Surrey SM2 SLT (telephone 01661 1611).

A day-release course leading to a Certificate in Therapentic Commenity Practice sponsored by the Association of Therapeutic Communities and the Royal College of Nursing will commence in October 1986. The course consists of three academic terms of 10 sessions (one afternoon/ evening per week) and will be held at the RCN in Cavendish Square, London W1. The fee is $\mathbf{2 3 7 5}$ (including two residential weekends) and the course is open to candidates of all disciplines in the hospital and social services. Further details and application form: Dr J. Stuart Whiteley, Henderson Hospital, 2 Homeland Drive, Brighton Road, Sutton, Surrey SM2 5LT or the Registrar, IANE, Royal College of Nursing, Cavendish Square, London W1.

The Third Ammal Congress of the Association of European Puycliatrists will be held at the Palais des Congres in Strasbourg on 23-25 October 1986. Further details: Professor L. Singer, c/o Secretariat, Third Annual AEP Congress, Clinique Psychiatrique, Hôpital Civil de Strasbourg, 1 Place de l'Hôpital, 67091 Strasbourg.

A course of weekly Seminars in Pyychotherapy will be conducted by John Steiner, Colin James, David Taylor and colleagues at the Tavistock Clinic beginning in October 1986 on Wednesday afternoons. Clinical seminar 2.00-3.15 p.m.; Theory seminar 3.30-4.30 p.m.; Candidates should be in personal analysis or psychotherapy or intend to embark on this in the course of the year. Applicants who are uncertain about this or about any other aspect of the course are invited to come and discuss their situation. Applications are invited now. Forms and further details: Miss Fay Reeves, Tavistock Clinic, 120 Belsize Lane, London NW3 5BA (telephone 014357111 ).
A course entitled A Puychodymamic Aprosech to Criltrea, Young People and their Famillies, designed for psychiatrists, social workers and other professional workers involved with children, is to be held under the auspices of the University of Birmingham (Uffculme Clinic) from October 1986 to July 1987. It will be run weekly. Information: Mrs Christine Neal, Centre for Postgraduate Psychiatry, Uficulme Clinic, Queensbridge Road, Moseley, Birmingham B13 8QD (telephone 0214494481 ).

A World Preveation Congress of Dres Use and Aleobolinam will be held in Nice, France from 31 August until 4 September 1986 at the Acropolis Palais des Congries Convention Center. It will be sponsored by the International Commission for the Prevention of Alcoholism and Drug Dependency (ICPA) and is under the patronage of the French Government's High Committee on Alcohol Studies and Information. Details: Victor Cooper, ICPA, 6830 Laurel Street, N.W., Washington, D.C. 20012-2199, USA (telephone 202722 6729).

Applications are invited from the Joint Academic Department of Psychiatry-the Middlesex Hospital Medical School-for a one year Diploma in Fanily Therapy course. The course consists of $1 \frac{1}{2}$ days per week formal academic tuition supplemented by clinical experience which can be gained either in Bloomsbury or in approved placements. Teaching staff will be drawn from the Marlborough Family Service, the Joint Academic Department and associated units, together with experts from related fields. Applicants must have a relevant professional qualification and hive completed some recognised introductory work in family therapy. Further information and application forms: Miss Ann Miller or Dr Alan Cooklin, Marlborough Family Service, 38 Marlborough Place, London NW8 OPJ (telephone 01 624 8605).

The Britich Aseociation of Psychotherapiess invites applicants for its four year post-graduate training in child psychotherapy commencing in October 1986. Prospectus and application forms: Mrs J. Lawrence, 121 Hendon Lane, London N3 3PR (telephone 01346 1747).

The Institute of Child Health (University of London) are holding a $1 \frac{1}{2}$ day course entitled Child Pyychiatry for the MRCPsych from 24-25 October 1986 organised by Professor Philip Graham. The fee is $\mathbf{1 4 0}$. Abstracts provided. Applications should be addressed to: The Clinical Teaching Office, Institute of Child Health, 30 Guilford Street, London WCIN IEH. 